\title{
Strong Radical Scavenging Macrofungi from the Dry Zone Forest Reserves in Sri Lanka
}

\author{
Dilusha Fernando ${ }^{1,2,3}$, Ravi Wijesundera ${ }^{1}$, Preethi Soysa ${ }^{2}$, Dilip de Silva ${ }^{3}$, \\ Chandrika Nanayakkara ${ }^{1}$ \\ ${ }^{1}$ Department of Plant Sciences, Faculty of Science, University of Colombo, Colombo, Sri Lanka
${ }^{2}$ Department of Molecular Biology and Biochemistry, Faculty of Medicine, University of Colombo, Colombo, Sri Lanka
${ }^{3}$ Department of Chemistry, Faculty of Science, University of Colombo, Colombo, Sri Lanka
}

Email address:

diluarchive@gmail.com (D. Fernando),ravi@pts.cmb.lk (R. Wijesundera), indunilsree@gmail.com (P. Soysa), dilip@chem.cmb.ac.lk (D.de Silva), hewa_nana@yahoo.com (C. Nanayakkara).

\section{To cite this article:}

Dilusha Fernando, Ravi Wijesundera, Preethi Soysa, Dilip de Silva, Chandrika Nanayakkara. Strong Radical Scavenging Macrofungi from the Dry Zone Forest Reserves in Sri Lanka. Frontiers in Environmental Microbiology. Vol. 1, No. 2, 2015, pp. 32-38.

doi: 10.11648/j.fem.20150102.15

\begin{abstract}
Natural metabolites produced by macrofungi are of great interest as potential antioxidant defensive agents to reduce the oxidative damage caused by free radicals. Primarily, phenolic and flavonoid type metabolites have gained major importance due to the strong capacity of scavenging free radicals. The study was mainly focused to investigate the natural antioxidant properties of macrofungi found in Sri Lankan dry zone forest reserves using DPPH radical scavenging assay and to find out the contribution of phenol and flavonoid substances towards their antioxidant capacity. $\mathrm{EC}_{50}$ values of all extracts were below $1.2 \mathrm{mg} / \mathrm{ml}$. Among the analyzed specimens, Phellinus repandus and Inonotus porrectus showed the most potent antioxidant activities having $\mathrm{EC}_{50}$ of $7.91 \pm 1.38 \mu \mathrm{g} / \mathrm{ml}$ and $19.70 \pm 0.17 \mu \mathrm{g} / \mathrm{ml}$, respectively. Ten fungal forms exhibited $\mathrm{EC}_{50}$ $<300 \mu \mathrm{g} / \mathrm{ml}$ and eighteen showed a mean values of $\mathrm{EC}_{50}$ in the range of 300-1200 $\mu \mathrm{g} / \mathrm{ml}$. Further, P. repandus and $I$. porrectus also exhibited the highest level of total phenols and flavonoids. $\mathrm{EC}_{50}$ values of the species studied were inversely related to the total phenol and flavonoid contents.The analyzed macrofungi specimens exhibited high antioxidant power highlighting their potential as therapeutically useful antioxidant agents. Particularly, P. repandus and I. porrectus could be an important source of novel antioxidant compounds. In addition, phenol and flavonoid compounds largely contribute to the scavenging activity of studied macrofungi.
\end{abstract}

Keywords: Macrofungi, Antioxidant Activity, Phenol Content, Flavonoid Content, $\mathrm{EC}_{50}$

\section{Introduction}

Macrofungi have an established history of use in traditional medical practices worldwide and considered to be a rich therapeutic source for the remedy of various deleterious diseases [1,2]. Macrofungi possess therapeutically useful important pharmacological properties including antioxidant, anticancer and anti-inflammatory activities. Moreover, mushrooms have rich nutritional value with a high protein content, vitamins, fibers, minerals, trace elements and natural antioxidants $[3,4]$.

Over 700 species of higher basidiomycetes have been identified to possess significant pharmacological properties $[5,6]$. Among the reported pharmacological properties of macrofungi, antioxidant activity studies have been emerging as an intensive research area aiming to develop nutritional and medicinal provisions for humankind owing to their strong ability to prevent radical mediated toxicity in the human body. All living cells, including human, animal and plant, are continuously exposed to a variety of challenges which exert oxidative stress brought on by a decrease in the antioxidant capacity of the system [7]. Oxidative stress leads to the generation of reactive oxygen species (ROS), including free radicals, which are strongly implicated in the pathophysiology of degenerative diseases associated with ageing, cancer, cardiovascular diseases and brain dysfunction $[8,9]$. Reactive oxygen species (ROS) include free radicals such as superoxide $\left(\mathrm{O}_{2}{ }^{\bullet}-\right)$, hydroxyl $\left(\mathrm{OH}^{\bullet}\right)$, hydroperoxyl $\left(\mathrm{OOH}^{\bullet}\right)$, peroxy $\left(\mathrm{ROO}^{\bullet}\right)$, alkoxy $\left(\mathrm{RO}^{\bullet}\right)$ radicals and non-free radicals including hydrogen peroxide $\left(\mathrm{H}_{2} \mathrm{O}_{2}\right)$ and hypochlorous acid $(\mathrm{HOCl})$, which are continuously produced in the human body during cell metabolism. Others are 
reactive nitrogen species (RNS) which include nitric oxide $\left(\mathrm{NO}^{\bullet}\right)$, peroxynitrite $\left(\mathrm{ONOO}^{\circ}\right)$ and nitrogen dioxide $\left(\mathrm{NO}_{2}\right)$ $[10,11]$. The abundance of free radicals is toxic to every biological molecule in living cells and can cause oxidative damage to functional macromolecules such as DNA, proteins, and lipids if not excluded quickly [12,13]. From all free radical species, $\mathrm{OH}^{\bullet}$ and $\mathrm{O}_{2}{ }^{\bullet-}$ radicals are the ones that are mainly responsible for the oxidative damage. Naturally, a dynamic balance exists between the amount of free radicals generated in the body and antioxidants to scavenge them to protect the body from harmful effects $[14,15]$. However, the endogenous mechanisms involved in free radical scavenging in the cell under normal physiological conditions may be inadequate to neutralize free radicals generated $[16,17]$. Hence, enriching the diet with antioxidants to protect the body against deleterious conditions has become essential. Antioxidants act as a major defense against radical mediated toxicity by protecting the damage caused by free radicals $[18,19]$.

Active secondary metabolites of some of the medicinal mushrooms such as Ganoderma lucidum, Pleurotus florida, Thelephora ganbajan, Agaricus bisporus, etc. were found to have promising antioxidant properties leading to the development of drug leads for the remedy of various degenerative diseases caused by radical mediated toxicity $[20,21]$. Among the secondary metabolites produced by macrofungi, bioactive phenols and flavonoid derivatives are of predominance due to their strong capacity for free radical scavenging [22,23]. Mainly, polyphenols have gained a higher importance in scavenging free radicals which is correlated to their chemical structure which consists of an aromatic ring with hydroxyl substituents. Therefore, there is a recent upsurge in the interest of mushrooms, due to their high content of polyphenol, which positively correlates with the antioxidant activity $[24,25,26,27]$.

Being a tropical country, Sri Lankan biota consists of a variety of wild-growing indigenous fungal species with medicinal and aromatic values. The mycological potential (both gastronomic and economic) of Sri Lanka is attributable to favourable climatic conditions and floral diversity. Approximately 1920 species of fungi have been identified from Sri Lanka, whilst the lack of data on the bioactive properties of wild-growing autochthonous fungal species has increased our interest in the current study [28]. Specifically, most of the mushrooms of Sri Lankan origin are unexplored to a large extent with substantial number of endemic species, many of which are possessing unknown chemical, biological and pharmacological profile. Further, ethno mycological research in Sri Lanka indicates only a rare use of fungi as food or internal medicinal provisions by indigenous practitioners in Sri Lanka [29]. The limited number of scientific research on medicinal importance of Sri Lankan fungal biota have prevented a giant pharmacological potential from being uncovered. Accordingly, it is worthwhile to investigate the bioactive properties of unexplored mushrooms in Sri Lanka to discover novel bioactive substances of fungal origin. The current study is an extended effort to uncover the antioxidant potential of macrofungi species harvested from the dry zone forest reserves in Sri Lanka and to determine the correlation of antioxidant capacity with total phenol and flavonoid contents of the crude methanolic extracts of macrofungi.

\section{Materials and Methodology}

\subsection{Collection of Macrofungi}

The specimens of macrofungi (30) were harvested from the dry zone forest reserves in Dambulla, Minneriya and Sigiriya areas of Sri Lanka during the period of September 2012 to October 2013. They were collected into paper bags and packed loosely with proper ventilation. The collected material was transported within 24 hours to the laboratory at Department of Plant Sciences, University of Colombo. The identity of the specimen was achieved by the Department of Plant Science, Faculty of science, University of Colombo, Sri lanka. Voucher specimens were deposited at the department herbarium of the same institute.

\subsection{Solvent Extraction}

Mature fruiting bodies of macrofungi were brush cleaned, dried in the oven at $40{ }^{\circ} \mathrm{C}$ to a constant mass and pulverized. A fine powder $(10 \mathrm{~g})$ of macrofungi sample was extracted by sonication with $150 \mathrm{ml}$ of methanol, methanol: dichloromethane (1:1) mixture and dichloromethane, respectively for 1 hour at $30^{\circ} \mathrm{C}$. Extracts were filtered twice through Whatman No. 1 filter and same extraction procedure was repeated for residue. Filtrates were combined and evaporated to dryness at $40{ }^{\circ} \mathrm{C}$ under reduced pressure using rotatory evaporator to obtain the crude extract. Crude extract was dissolved in methanol and used for further experiments.

\subsection{Determination of Antioxidant Activity}

Antioxidant activity was determined by 1, 1-Diphenyl-2Picrylhydrazyl (DPPH) scavenging assay according to a previously described method with modifications [30]. Different concentrations $(0.01-10 \mathrm{mg} / \mathrm{ml})$ of crude extract were prepared in methanol. The effective concentration range was determined by performing a pretest. A volume of $100 \mu \mathrm{l}$ of the test solution was added to $900 \mu \mathrm{l}$ of DPPH $(100 \mu \mathrm{M})$ solution and incubated for 30 minutes in dark at $30{ }^{\circ} \mathrm{C}$. Thereafter, absorbance was measured at $517 \mathrm{~nm}$ using a UVVisible spectrophotometer (SHIMADZU AEG-220). Ascorbic acid was used as the positive standard antioxidant. Blank is consisted of DPPH $(900 \mu \mathrm{l})$ dissolved in the of 100 $\mu 1$ of methanol. The DPPH radical scavenging activity or antioxidant index (\%) was calculated by using the following formula:

DPPH radical scavenging activity $(\%)=\left[\left(\mathrm{A}_{\text {control }}-\mathrm{A}_{\text {extract }} /\right.\right.$ $\mathrm{A}_{\text {control }} * 100$

Where $\mathrm{A}_{\text {control }}$ is the absorbance of blank, and $\mathrm{A}_{\text {extract }}$ is the absorbance of the test solution. The effective concentration of sample required to scavenge DPPH radical by $50 \%\left(E_{50}\right)$ was obtained by linear regression analysis of dose response 
curve plotted with radical scavenging activity (\%) and concentration of the mushroom extract.

\subsection{Determination of Total Phenol Content}

Total phenol content of the methanol extracts was determined by the Folin - Ciocalteau method [31]. Folinciocalteu reagent $(1 \mathrm{~N} ; 250 \mu \mathrm{l})$ was added to $500 \mu \mathrm{l}$ of test solution and incubated for 2 minutes. Then, a volume of 1.25 $\mathrm{ml}$ of $10 \% \mathrm{Na}_{2} \mathrm{CO}_{3}$ was added to the mixture and incubated for 45 minutes at room temperature. Absorbance was measured at $760 \mathrm{~nm}$ using UV-visible spectrophotometer. A calibration curve was constructed using gallic acid at a concentrations range of $3-40 \mu \mathrm{g} / \mathrm{ml}$. The total phenol contents of the samples were expressed as mg of gallic acid equivalents (GAEs) per gram of dry sample.

\subsection{Determination of Total Flavonoid Content}

Total flavonoid content was determined by the slightly modified method of aluminium chloride colorimetric assay [32]. Sodium nitrite $(5 \% ; 30 \mu \mathrm{l})$, methanol $(98 \% ; 200 \mu \mathrm{l})$ and aluminium chloride $(10 \% ; 30 \mu \mathrm{l})$ was added to $100 \mu \mathrm{l}$ of test solution and incubated for 5 minutes at $30{ }^{\circ} \mathrm{C}$. Sodium hydroxide $(1 \mathrm{M} ; 200 \mu \mathrm{l})$ was added at the sixth minute followed by $0.44 \mathrm{ml}$ of methanol $(98 \%)$. The absorbance of the resulting solution was measured at $510 \mathrm{~nm}$. Calibration curve was obtained using (-)-Epigallocatechingallate (EGCG) at a concentrations range of $15-500 \mu \mathrm{g} / \mathrm{ml}$. The total flavonoid contents were expressed as w/w \% EGCG equivalents.

\subsection{Statistical Analysis}

All experiments were carried out in triplicate. The effective concentration of sample required to scavenge radicals by $50 \%\left(\mathrm{EC}_{50}\right)$ was obtained by linear regression analysis of the dose response curve. Graphical data were presented as mean \pm standard deviation of the mean (SD).

\section{Results and Discussion}

\subsection{Antioxidant Activity}

Macrofungi are found to be a rich source of natural antioxidants with immense radical scavenging activity. Accordingly, antioxidant substances found in mushrooms can act as major protectors against radical mediated toxicity generated in the biological systems. Epidemiological studies also have demonstrated that many of these antioxidant compounds possess anti-inflammatory, antiatherosclerotic, antitumor, antibacterial, or antiviral activities to a greater or lesser extent signifying the importance of natural antioxidants found in mushrooms [33,34].

In the present study, antioxidant activity of 30 macrofungi species was screened for antioxidant potential using DPPH radical scavenging assay which is commonly used and highly demanding method for assessing antioxidant activity of biogenic fractions of plants and mushrooms. DPPH is a stable free radical which is reduced to DPPH - $\mathrm{H}$ in the presence of a free radical scavenger. Consequently, the absorbance is decreased from the DPPH radical to DPPH - $\mathrm{H}$ form leading to provide a characteristic absorption at $517 \mathrm{~nm}$ in the visible region of electromagnetic spectrum. When antioxidants donate protons to these radicals, characteristic deep purple colour of the DPPH solution become reduced. The degree of discolouration correlates with the scavenging potential of the antioxidant compounds in the extracts in terms of hydrogen donating ability. The decrease in absorption is used as a measure of the extent of DPPH free radical scavenging activity [35,36]. Radical scavenging capacity was found to be inversely related to the $\mathrm{EC}_{50}$ values of the investigated species [37,38]. In this investigation, all macrofungal extracts exhibited high antioxidant potential to variable levels (Table 1). Among the analyzed forms, the most potent radical scavenging effect was observed for Phellinus repandus and Inonotus porrectus showing remarkably lower $\mathrm{EC}_{50}$ values of $7.90 \pm 1.38 \mu \mathrm{g} / \mathrm{ml}$ and $19.70 \pm 0.17 \mu \mathrm{g} / \mathrm{ml}$, respectively, compared to the $\mathrm{EC}_{50}$ of standard antioxidant, ascorbic acid $\left(\mathrm{EC}_{50} ; 5.00 \pm 0.13 \mu \mathrm{g} / \mathrm{ml}\right)$. The dose response curves of DPPH radical scavenging capacity $\%$ and concentration of the crude methanolic extracts of $P$. repandus and $I$. porrectus were represented in Figure 1. Figure 1 describes an increase in DPPH free radical scavenging activity with the increase in concentration of the macrofungal extracts of $P$. repandus and $I$. porrectus in the initial phase of the dose response curve until it becomes static (Figure 1).

Ganoderma applanatum, Gyrodontium sacchari, Fuscoporia gilva also showed potent antioxidant activities with $\mathrm{EC}_{50}$ values of $50.40 \pm 0.43 \mu \mathrm{g} / \mathrm{ml}, 56.70 \pm 0.14$ and $44.08 \pm 1.27 \mu \mathrm{g} / \mathrm{ml}$, respectively. Interestingly, other analysed extracts also exhibited high antioxidant potential, with lower $\mathrm{EC}_{50}$ values below $1.2 \mathrm{mg} / \mathrm{ml}$, ten forms exhibited $\mathrm{EC}_{50}<300 \mu \mathrm{g} / \mathrm{ml}$ and eighteen forms showed a mean value of $\mathrm{EC}_{50}$ in the range of $300-1200 \mu \mathrm{g} / \mathrm{ml}$. The antioxidant properties assayed herein were summarized in Table 1 and the results were expressed as $\mathrm{EC}_{50}$ values ( $\mu \mathrm{g}$ various extracts per $\mathrm{ml}$ ).

Table 1. EC 50 values (mean \pm SD) obtained in the DPPH antioxidant assays of 30 macrofungi species ${ }^{*}$ Each value is expressed as mean \pm standard deviation $(n=3)]$.

\begin{tabular}{lll}
\hline Name & EC $_{\mathbf{5 0}}(\boldsymbol{\mu} \mathbf{g} / \mathbf{m l})$ & Specimen no. in the Department's herbarium \\
\hline Coriolopsis aspera & $123.01 \pm 0.58$ & UOC:DAMIA:D01 \\
Schizophyllum commune & $425.00 \pm 0.65$ & UOC:DAMIA:D05 \\
Polyporus arcularius & $943.00 \pm 0.75$ & UOC:DAMIA:D08 \\
Stereum hirsutum & $630.01 \pm 0.23$ & UOC:DAMIA:D09 \\
Xylaria papulis & $289.04 \pm 0.67$ & UOC:DAMIA:D11 \\
\hline
\end{tabular}




\begin{tabular}{lll}
\hline Name & $\mathbf{E C}_{\mathbf{5 0}}(\boldsymbol{\mu g} \mathbf{g} \mathbf{m l})$ & Specimen no. in the Department's herbarium \\
\hline Hexagonia tenuis & $531.70 \pm 1.01$ & UOC:DAMIA:D12 \\
Coriolopsis byrsina & $557.01 \pm 1.14$ & UOC:DAMIA:D13a \\
Earliella scabrosa & $1088.70 \pm 1.38$ & UOC:DAMIA:D13b \\
Coriolopsis caperata & $365.01 \pm 0.45$ & UOC:DAMIA:D13d \\
Hexagonia apiaria & $91.50 \pm 0.65$ & UOC:WASNP:W09 \\
Microporus vernicipes & $552.70 \pm 1.38$ & UOC:DAMIA:D16 \\
Flavodon flavus & $77.06 \pm 0.005$ & UOC:DAMIA:D19 \\
Polyporus grammocephalus & $951.01 \pm 1.12$ & UOC:DAMIA:D39 \\
Podoscypha petalodes & $720.20 \pm 0.087$ & UOC:DAMIA:D44 \\
Trichaptum byssogenum & $555.51 \pm 0.22$ & UOC:SIGWI:S10 \\
Pycnoporus coccineus & $254.67 \pm 0.44$ & UOC:SIGWI:S19 \\
Trametes elegans & $198.75 \pm 0.48$ & UOC:SIGWI:S25 \\
Inonotus porrectus & $19.70 \pm 0.17$ & UOC:SIGWI:S61 \\
Daldinia eschscholtzii & $735.77 \pm 0.76$ & UOC:SIGWI:S29 \\
Phanerochaete chrysosporium & $69.06 \pm 0.12$ & UOC:SIGWI:S44 \\
Termitomyces heimii & $1120.10 \pm 0.014$ & UOC:DAMIA:D43 \\
Gyrodontium sacchari & $56.70 \pm 0.14$ & UOC:MINNP:MK05 \\
Ganoderma applanatum & $50.40 \pm 0.43$ & UOC:KAUNP:MK24 \\
Ganoderma tusage & $64.40 \pm 0.45$ & UOC:KAUNP:MK25 \\
Fuscoporia gilva & $44.08 \pm 1.27$ & UOC:MINNP:MK71 \\
Xylaria schweinitzii & $331.10 \pm 1.17$ & UOC:MINNP:MK33b \\
Phellinus repandus & $7.91 \pm 1.38$ & UOC:DAMIA:D27a \\
Xylaria feejeensis & $83.70 \pm 1.11$ & UOC:MINNP:MK34 \\
Gymnopilus lepidotus & $322.10 \pm 1.21$ & UOC:KAUNP:MK64 \\
Hymenochaete rubiginosa & $227.07 \pm 0.59$ & UOC:SIGWI:S55 \\
\hline
\end{tabular}

$P$. repandus and $I$. porrectus are terrestrial basidiomycetes which belong to the family hymenochaetaceae. Majority of the species in this family are of medicinal value, while some are plant pathogens causing a white rot [39]. However, yet there are no reports available on bioactive properties of $P$. repandus and $I$. porrectus.

The DPPH radical scavenging activity evaluated as $\mathrm{EC}_{50}$ values for Phellinus spp. namely Phellinus gilvus, Phellinus rimosus and Phellinus badius was $9 \mathrm{mg} / \mathrm{ml}, 10 \mathrm{mg} / \mathrm{ml}$ and
$13 \mathrm{mg} / \mathrm{ml}$ respectively [40]. P. repandus exhibited a strong antioxidant power compared to $\mathrm{EC}_{50}$ values reported for $P$. gilvus, $P$. rimosus, $P$. badius. Lentinula edodes which is a widely used edible fungus also belongs to this family. It has been reported that the $\mathrm{EC}_{50}$ of Lentinula edodes for methanol extract against DPPH antioxidant assay was $4.4 \mathrm{mg} / \mathrm{ml}$ [41]. Interestingly, I. porrectus was found to possess a compelling radical scavenging activity compared to the antioxidant capacity of $L$. edodes.

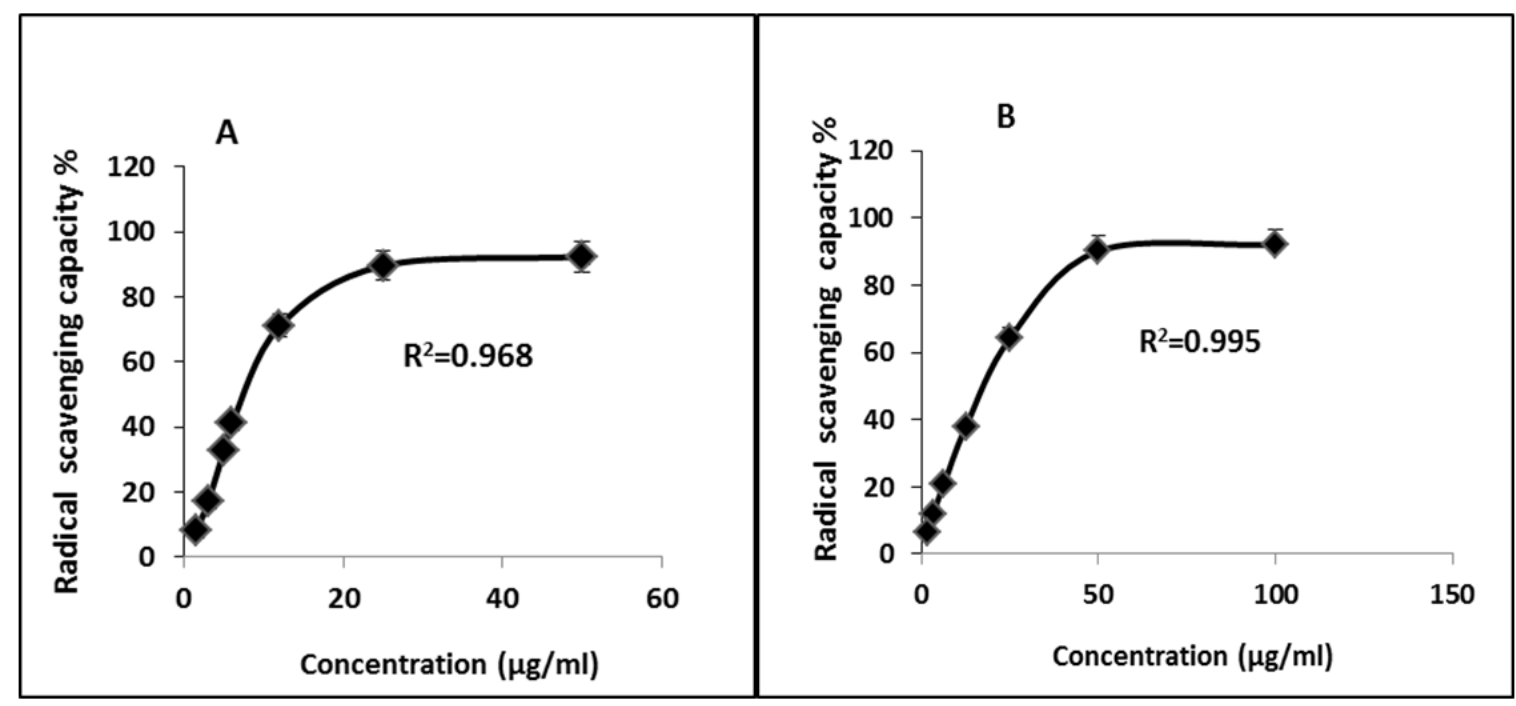

Fig. 1. Dose response curves of DPPH radical scavenging capacity \% for methanolic extracts of A) P. repandus B) I. porrectus.

In addition, Ganoderma lucidum is an important medicinal mushroom used in the modern world, acclaimed as "mushroom of immortality" which belongs to Polyporaceae family [42,43]. Hot water extract of Ganoderma lucidum was found to have a $\mathrm{EC}_{50}$ of $5.28 \mathrm{mg} / \mathrm{ml}$ against DPPH scavenging assay [44]. Methanolic extracts of Ganoderma lucidum exhibited free radical scavenging effect on the 1,1-diphenyl-2-picrylhydrazyl radical with an $\mathrm{EC}_{50}$ value of $1.162 \pm 0.016 \mathrm{mg} / \mathrm{ml}$ [45]. Currently, the active component which exert antioxidant and anticancer properties of Ganoderma lucidum has been identified, isolated and developed as a dietary supplement [46]. Intriguingly, in our investigation, P. repandus and I. porrectus showed a remarkable radical scavenging effect which is 
considerably greater than the "mushroom of immortality", $G$. lucidum. Above innovation implies the propensity of these species to act as leading sources of therapeutically useful biologically active agents.

\subsection{Total Phenol and Flavonoid Contents}

Total phenol content and flavonoid content of the each species were determined and the correlation with antioxidant capacity was also investigated. Further, P. repandus and I. porrectus showed the highest level of total phenols $(266.01 \pm 5.89 \mu \mathrm{g}$ Gallic acid/ $\mathrm{mg}$ and
$75.01 \pm 3.16 \mu \mathrm{g}$ Gallic acid/mg, respectively) as well as highest quantity of total flavonoids $(175.10 \pm 4.56 \mu \mathrm{g}$ Epicatechine $/ \mathrm{mg}$ and $52.20 \pm 3.13 \mu \mathrm{g}$ Epicatechine/mg, respectively) suggesting that phenolic and flavonoid compounds largely contribute to the strong antioxidant activity of these 2 species.

The total phenol and flavonoid contents of all the macrofungal specimens analyzed herein were summarized in Table 2 and the total phenol content were expressed as TPC ( $\mu \mathrm{g} \mathrm{GAE} / \mathrm{mg})$ and total flavonoid content was indicated as TFC ( $\mu \mathrm{g} \mathrm{EC} / \mathrm{mg})$.

Table 2. Total Phenol Content ( $\mu \mathrm{g}$ GAE/mg) and Total Flavonoid Content ( $\mu \mathrm{g}$ EC/mg) of the crude methanolic extracts of 30 macrofungi species ["Each value is expressed as mean \pm standard deviation $(n=3)]$.

\begin{tabular}{|c|c|c|}
\hline Name & Mean Value-TPC ( $\mu \mathrm{g}$ GAE/mg) & Mean Value-TFC ( $\mu \mathrm{g}$ EC/mg) \\
\hline Coriolopsis aspera & $16.5 \pm 1.10$ & $5.4 \pm 0.99$ \\
\hline Schizophyllum commune & $4.21 \pm 1.21$ & $2.01 \pm 1.32$ \\
\hline Polyporus arcularius & $5.6 \pm 0.21$ & $11.45 \pm 1.32$ \\
\hline Stereum hirsutum & $11.6 \pm 1.22$ & $3.2 \pm 0.43$ \\
\hline Xylaria papulis & $15.48 \pm 0.43$ & $6.6 \pm 1.44$ \\
\hline Hexagonia tenuis & $5.9 \pm 1.46$ & $4.02 \pm 1.55$ \\
\hline Coriolopsis byrsina & $7.5 \pm 1.78$ & $2.7 \pm 0.55$ \\
\hline Earliella scabrosa & $9.41 \pm 1.65$ & $9.41 \pm 1.25$ \\
\hline Coriolopsis caperata & $20.7 \pm 0.45$ & $1.44 \pm 1.65$ \\
\hline Hexagonia apiaria & $16.1 \pm 0.25$ & $24.4 \pm 0.65$ \\
\hline Microporus vernicipes & $7.4 \pm 1.12$ & $1.2 \pm 1.10$ \\
\hline Flavodon flavus & $55.7 \pm 0.65$ & $82.4 \pm 1.03$ \\
\hline Polyporus grammocephalus & $5.01 \pm 1.65$ & $2.12 \pm 1.23$ \\
\hline Podoscypha petalodes & $7.01 \pm 1.23$ & $4.23 \pm 1.43$ \\
\hline Trichaptum byssogenum & $9.12 \pm 1.02$ & $8.01 \pm 1.10$ \\
\hline Pycnoporus coccineus & $12.32 \pm 1.24$ & $9.97 \pm 1.22$ \\
\hline Trametes elegans & $15.09 \pm 0.89$ & $11.92 \pm 1.12$ \\
\hline Inonotus porrectus & $75.01 \pm 3.16$ & $52.20 \pm 3.13$ \\
\hline Daldinia eschscholtzii & $9.93 \pm 1.15$ & $8.89 \pm 1.54$ \\
\hline Phanerochaete chrysosporium & $80.98 \pm 0.95$ & $45.78 \pm 1.22$ \\
\hline Termitomyces heimii & $5.01 \pm 1.41$ & $4.02 \pm 1.15$ \\
\hline Gyrodontium sacchari & $63.03 \pm 1.14$ & $61.21 \pm 1.21$ \\
\hline Ganoderma applanatum & $146.21 \pm 1.18$ & $135.34 \pm 1.24$ \\
\hline Ganoderma tusage & $105.89 \pm 1.22$ & $98.09 \pm 1.23$ \\
\hline Fuscoporia gilva & $64.09 \pm 1.14$ & $60.21 \pm 1.21$ \\
\hline Xylaria schweinitzii & $14.12 \pm 1.65$ & $8.90 \pm 1.54$ \\
\hline Phellinus repandus & $266.01 \pm 5.89$ & $175.10 \pm 4.56$ \\
\hline Xylaria feejeensis & $49.24 \pm 1.12$ & $39.12 \pm 1.25$ \\
\hline Gymnopilus lepidotus & $13.90 \pm 1.12$ & $7.99 \pm 1.45$ \\
\hline Hymenochaete rubiginosa & $14.76 \pm 1.26$ & $8.96 \pm 1.21$ \\
\hline
\end{tabular}
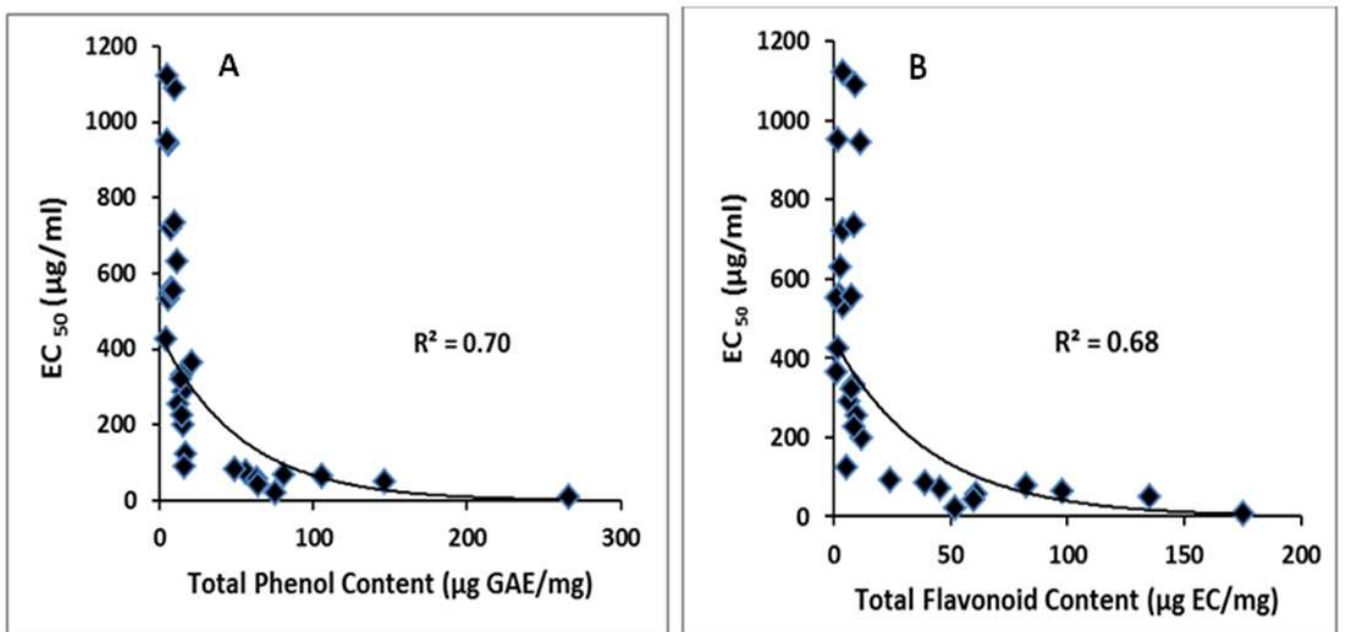

Fig. 2. A) Correlation between $E C_{50}$ values of the macrofungi species and total Phenol content B) Correlation between EC $C_{50}$ values and total flavonoid content. 
$\mathrm{EC}_{50}$ values of all the species studied were plotted against total phenol and flavonoid contents and correlation of antioxidant activitiy of macrofungi with total phenol content and flavonoid content of the macrofungi was investigated. Intriguingly, those $\mathrm{EC}_{50}$ values of the species were inversely related to the total phenol and flavonoid contents of the macrofungi extracts implying the contribution of these compounds to their strong antioxidant activities (Figure 2).

To the best for our knowledge, this is the first report on antioxidant activity, total phenol and flavonoid content of $P$. repandus and $I$. porrectus. The rich antioxidant contents of $P$. repandus and $I$. porrectus species make them ideal as nutritional supplements with good medicinal properties. Since the antioxidant activites of $P$. repandus and $I$. porrectus are very high, the isolation and characterization of bioactive compounds from these species are underway to identify potential antioxidant agents for the treatment of degenerative diseases associated with free radicals. Potential antioxidant compounds can be developed as dietary supplements with natural antioxidant properties or as a pharmaceutical composition that can be admixtured with one or more pharmaceutically acceptable carriers. Compositions may also include flavours, colourings and coatings. However, added agents must be non-toxic and should not strikingly interfere with the activity of the metabolites of the macrofungi. In addition, it can be added to fruit juice, vegetable juice or all kinds of nutrient drinks containing nutraceuticals of choice such as vitamins, minerals.

\section{Conclusion}

In conclusion, all analyzed macrofungi species harvested from the dry zone of Sri lanka possess high antioxidant power. Specifically, P. repandus and I. porrectus showed promising antioxidant activities and high content of phenols and flavonoid substances implying their importance as a potential sources of novel antioxidant compounds. Moreover, phenol and flavonoid contents showed a inverse correlation with $\mathrm{EC}_{50}$ values of each species suggesting that phenolic and flavonoid compounds are largely responsible for the antioxidant activity of analyzed macrofungi. Interestingly, present findings display the importance of isolation and characterization of bioactive compounds from these macrofungi species.

\section{References}

[1] U. Lindequist, T. H. J. Niedermeyer and W. Julich, The Pharmacological Potential of Mushrooms. eCAM 2 (3): 285299, 2005.

[2] A. Turkoglu, M. E. Duru and N. Mercan Antioxidant and Antimicrobial Activity of Russula delica Fr: An Edidle Wild Mushroom. Eurasian J Anal Chem 2 (1): 54-67, 2007.

[3] G.S. Jose and P. M. Radhamany. Identification and determination of antioxidant constituents of bioluminescent mushroom. Asian Pacific J of Tropical Biomedicine S386S391, 2012.

[4] L. Fan, H. Pan, A. T. Soccol, A. Pandey and C. R. Socco. Advances in Mushroom Research in the Last Decade. Advances in Mushroom Research, Food Technol. Biotechnol 44(3): 303-311, 2006.

[5] T. A. Ajith and K. K. Janardhanan. Indian Medicinal Mushrooms as a Source of Antioxidant and Antitumor Agents. J. Clin. Biochem. Nutr 40: 157-162, 2007.

[6] S. P. Wasser and A. L.Weis. Medicinal propreties of substances occurring in higher basidiomycetes mushrooms: current perspectives. J Medicinal mushrooms 1: 31-62, 1999.

[7] L. Barros, S. Falcão, P. Baptista, C. Freire, M. Vilas-Boas and I. C. F. R. Ferreira. Antioxidant activity of Agaricus sp. mushrooms by chemical, biochemical and electrochemical assays.J. FoodChem 111: 61-66, 2008.

[8] A. R. Sharma and M. N. Noolvi. Natural sources as potential anti-cancer agents: A review. J Phytomedicine 3: 09-26, 2011.

[9] A. S. Ravipati, L. Zhang, S. R. Koyyalamudi, S. C. Jeong, N Reddy, J. Bartlett, P. T. Smith, K. Shanmugam, Wu. M. J. Münch, M. Satyanarayanan and B. Vysetti. Antioxidant and anti-inflammatory activities of selected Chinese medicinal plants and their relation with antioxidant content. BMC Complementary and Alternative Medicine 12:173-187, 2012.

[10] K. H. Cheeseman and T. F. Slater. An introduction to free radical biochemistry. Br Med Bull 49: 481-493, 1993.

[11] H. Liu and G. A. Visner. Oxidants and antioxidants. In Molecular Pathology of Lung Diseases. Edited by Zander DS, Popper HH, Jagirdar J, Haque AK, Cagle PT, Barrios R: Springer 470-475, 2008.

[12] P. Diaz, S. C. Jeong, S. Lee, C. Khoo and S. R. Koyyalamudi. Antioxidant and anti-inflammatory activities of selected medicinal plants and fungi containing phenolic and flavonoid compounds. Chinese Medicine 7: 26-35, 2012.

[13] L. Zhang, A. S. Ravipati, S. R. Koyyalamudi, S. C. Jeong, N Reddy, P.T. Smith, J. Bartlett, K. Shanmugam, D. G. Münch and M. J. Wu. Antioxidant and anti-inflammatory activities of selected medicinal plants containing phenolic and flavonoid compounds.J Agr Food Chem 59: 12361-12367, 2011.

[14] A. K. Tiwari. Imbalance in antioxidant defect and human diseases Multiple approach of natural antioxidants therapy. CURRENT SCIENCE 81(9): 1179-1187, 2001.

[15] E. A. Adebayo, J. K. Oloke, A. A. Ayandele and C. O. Adegunlola. Phytochemical, antioxidant and antimicrobial assay of mushroom metabolite from Pleurotus pulmonarius. J. Microbiol. Biotech. Res 2 (2): 366-374, 2012.

[16] D. D. Tibuhwa. Antiradical and antioxidant activities of methanolic extracts of indigenous termitarian mushroom from Tanzania. Food Science and Quality Management 7: 13-23, 2012.

[17] J. Liu, Y. Wu, J. Kan, Y. Wang and C. Jin. Changes in reactive oxygen species production and antioxidant enzyme activity of Agaricus bisporus harvested at different stages of maturity. J Sci Food Agric 93: 2201-2206, 2013. 
[18] A. Keles, I. Koca and H. Gençcelep. Antioxidant Properties of Wild Edible Mushrooms. J Food Process Technol 2: 1-6, 2011.

[19] I. C. F. R. Ferreira, P. Baptista,, M. Vilas-Boas and L. Barros. Free-radical scavenging capacity and reducing power of wild edible mushrooms from northeast Portugal: Individual cap and stipe activity. Food Chemistry 100: 1511-1516, 2007.

[20] M. Karaman, E. Jovin, R. Malbaša, M. Matavuly and M. Popovic. Medicinal and Edible Lignicolous Fungi as Natural Sources of Antioxidative and Antibacterial Agents. Phytother Res 24: 1473-1481, 2010.

[21] J. Savoie, N. Minvielle and M. L. Largeteau. Radicalscavenging properties of extracts from the white button mushroom, Agaricus bisporus. J Sci Food Agric 88: 970-97, 2008.

[22] I. Mujic, Z. Zekovic, Z. Lepojevic, S. Vidovic and J. Zivkovic. Antioxidant properties of selected edible mushroom species. J Central European Agriculture 11(4): 387-392, 2010.

[23] F. Kalyoncu, M. Oskay and H. Kayalar. Antioxidant activity of the mycelium of 21 wild mushroom species. J Mycology 1(3): 195-199, 2010.

[24] J. Y. Wong and F. Y. Chye. Antioxidant properties of selected tropical wild edible mushroom. J Food Composition and Analysis 22: 269-277, 2009.

[25] A. C. Ramırez-Anguiano, S. Santoyo, G. Reglero and C. Soler-Rivas. Radical scavenging activities, endogenous oxidative enzymes and total phenols in edible mushrooms commonly consumed in Europe. J Sci Food Agric 87: 2272 $2278,2007$.

[26] E. Alvarez-Parrilla, L. A. de la Rosa, N. R. Martínez and G. A. G. Aguilar. Total phenols and antioxidant activity of commercial and wild mushrooms from chihuahua, mexico. Cienc Tecnol Aliment 5(5): 329-334, 2007.

[27] O. V. Oyetayo, A. Nieto- Camacho, T. M. Ramırez-Apana, R. E. Baldomero, M. Jimenez. Total Phenol, Antioxidant and Cytotoxic Properties of Wild Macrofungi Collected from Akure Southwest Nigeria. Jordan J of Biological Sciences 6(2): 105-110, 2008.

[28] K. W. Samarakoon, J. Lee, E. D. De Silva, E. Kim, R. L. C. Wijesundara, H. H. C. Lakmal and Y. Jeon. Bioactivity evaluation of organic solvent extractions of Ganoderma lucidum: a Sri Lankan basidiomycete. J.Natn.Sci.Foundation Sri Lanka 41 (3): 249-257, 2013.

[29] S. C. Karunarathna, D. Udayanga, S. N. Maharachchikumbura, M. Pilkington, D. S. Manamgoda, D. N. N. Wijayawardene, H. A. Ariyawansa, A. R. Bandara, E. Chukeatirote, E. H. C. McKenzie and K. D. Hyde. Current status of knowledge of Sri Lankan mycota. Current Research in Environmental \& Applied Mycology 2(1):18-29, 2012.

[30] L. K. Silva and P. Soysa. Evaluation of phytochemical composition and antioxidant capacity of a decoction containing adenanthera pavonina $L$ and Thespesia populnea $L$. Pharmacogn Mag 7: 193-199, 2011.

[31] P. Soysa, I. S. De Silva and J. Wijayabandara. Evaluation of antioxidant and Antiproliferative activity of Flueggea leucopyrus Willd (katupila). BMC Complementary and Alternative Medicine 14: 274-282, 2014.

[32] C. Chang, M. Yang, H. Wen and J. Chern. Estimation of total flavonoid content in propolis by two complementary colorimetric methods. J Food and Drug Anal 10:178-182, 2002.

[33] B. Halliwell. Free radicals, antioxidants, and human disease: curiosity, cause, or consequence. Lancet 344 (8924), 721-724, 1994.

[34] L. A. Mitscher, H. Telikepalli, E. McGhee and D. M. Shankel. Natural antimutagenic agents. Mutation Research 350 (1), 142-143, 1996.

[35] T. Kulisic, A. Radonic, V. Katalinic and M. Milos. Use of different methods for testing antioxidative activity of oregano essential oil. Food Chemistry 85: 633-640, 2004.

[36] T. Riaz, M.A. Abbasi, Aziz-ur-rehman, T. Shahzadi, M. Ajaib and K.M. Khan. Phytochemical screening, free radical scavenging, antioxidant activity and phenolic content of Dodonaea viscose Jacq. J Serb Chem Soc 77(4): 423-435, 2012.

[37] N. Pise, K. Jena, D. Maharana, D. Gaikwad and T. Jagtap. Free radical scavenging potential, reducing power, phenolic and biochemical constituents of Porphyra species from India. J. Algal Biomass Utln 1(3): 29-42, 2010.

[38] A. Kumar, N. S. Kumari and D. Bhargavan. Evaluation of in vitro antioxidant potential of ethanolic extract from the leaves of Achyranthes aspera. Asian J Pharm Clin Res 5(3): 146-148, 2012.

[39] S. S Ediriweera, R. L. C. Wijesundera, C.M. Nanayakkara, O. V. D. S. J. Weerasena. A new record of Fulvifomes fastuosus from Sri Lanka. J.Natn.Sci.Foundation Sri Lanka 42 (4):375-377, 2014.

[40] J. F. Ayala-Zavala, B. A. Silva-Espinoza, M. R. Cruz-Valenzuela, M. A. Villegas-Ochoa, M. Esqueda, G. A. González-Aguilar and Y. Calderón-López. Antioxidant and antifungal potential of methanol extracts of Phellinus spp. from Sonora, Mexico. Rev Iberoam Micol 29 (3): 132-138, 2012.

[41] S. Sasidharan, S. Aravindran S, L. Y. Latha, R. Vijenthi, D. Saravanan and S. Amutha. In Vitro Antioxidant Activity and Hepatoprotective Effects of Lentinula edodes against Paracetamol-Induced Hepatotoxicity. Molecules 15: 4478$4489,2010$.

[42] J. Li, J. Zhang, H. Chen, X. Chen, J. Lan and C. Liu. Complete Mitochondrial Genome of the Medicinal Mushroom Ganoderma lucidum. PLOS ONE 8 (8): e72038, 2013.

[43] R. Baskar, R. Lavanya, S. Mayilvizhi and P. Rajasekaran. Free radical scavenging activity of antitumour polysaccharide fractions isolated from Ganoderma lucidum (Fr.) P. karst.Natural product radiance 7(4): 320-325, 2008.

[44] M. Rajasekaran and C. Kalaimagal. In Vitro Antioxidant Activity of Ethanolic Extract of a Medicinal Mushroom, Ganoderma Lucidum. J Pharm Sci \& Res 3(9): 427-1433, 2011.

[45] A. Rawat, M. Mohsin, P. S. Negi, A. N. Sah and S. Singh. Evaluation of polyphenolic contents and antioxidant activity of wildly collected Ganoderma lucidum from central Himalayan hills of India. Asian J Plant Sci Res 3 (3): 85-90, 2013.

[46] A. Nahata. Ganoderma lucidum: A Potent Medicinal Mushroom with Numerous Health Benefits Pharmaceut Anal Acta 4 (10): 1000e159, 2013. 